Watson, S. W. \& RAPER, K. B. (1957). J. gen. Microbiol. 17, 368-377

\title{
Labyrinthula minuta sp.nov.
}

\author{
By S. W. WATSON AND K. B. RAPER \\ Department of Bacteriology, University of Wisconsin, Madison, Wisconsin, \\ U.S.A.
}

\begin{abstract}
SUMMARY: A new marine species of Labyrinthula is described for which the name L. minuta is proposed because of its diminutive proportions. This species has been isolated repeatedly from Ulva lactuca and other algae collected from the Atlantic Ocean in the region of Woods Hole, Massachusetts. The vegetative stage, as in other species of Labyrinthula, consists of independent cells interconnected by threads of slime which form a net-like structure called the net-plasmodium. $L$. minuta differs from all previously described species of this genus in the size, shape, and movement of its cells, in its method of cell division, its colonial morphology and by the formation in aged cultures of multinucleate bodies which resemble miniature plasmodia. No fructification has yet been observed. This species has been grown in pure reproducible laboratory culture on a serum + sea water medium for a period of five years.
\end{abstract}

The genus Labyrinthula is composed of unicellular, aquatic micro-organisms that are characterized by a gliding motility on self-formed slime filaments. Extension, branching, and anastomosis of such filaments connect the cells together into a colony (Pl. 1, figs. 1, 2). Such a colony, when viewed under low magnification on an agar surface, presents a view of a finely meshed network often called a net-plasmodium (Zopf, 1892). The unique mobility of the cells restricted to the pre-formed slime tracts distinguishes Labyrinthula from all other known genera in the plant and animal kingdoms.

Cienkowski (1867) established the genus Labyrinthula with the description of two marine species, $L$. vitellina and L. macrocystis. Following this, two freshwater species were recorded as $L$. cienkowskii by Zopf (1892) and L. zopfii by Dangeard (1910). Later, Valkanov (1929) assigned the name L. zopfii to a marine form, not realizing that Dangeard had already applied this name to a freshwater species. In 1932 Dangeard reported another marine species as $L$. chattonii. Upon reviewing the reports of these six species, Young (1943) proposed a consolidation into three species and two varieties, and suggested that 'further investigations might even reduce these to a single species'.

Inadequate and possibly inaccurate descriptions exist for two additional organisms which probably belong to this genus, namely: Labyrinthomyxa sauvageaui Duboscq (1921) and Chlamydomyxa labyrinthuloides Archer (1875). Additionally, Pseudoplasmodium aurantiacum, described by Molisch (1926) as a new genus of the Acrasieae, almost certainly represents a species of Labyrinthula.

The conflicting and often fragmentary nature of the published reports on Labyrinthula is believed to result in substantial measure from the impure and non-reproducible laboratory cultures studied by earlier investigators. Watson \& Ordal (1957) recently developed techniques for obtaining pure 
cultures of Labyrinthula, and L. minuta was isolated and cultivated on serum + sea water agar by application of the methods described by them. This species differs from all other described members of the genus in one or more of the following characteristics: cell size, cell shape, cell movement, mode of division, formation of a multinucleate stage, and colonial morphology. These distinguishing characteristics have remained constant with each periodic transfer of laboratory cultures maintained for the past five years. The binominal L. minuta is applied to the new species because of the diminutive proportions of its cellular elements.

\section{TECHNICAL DESCRIPTION}

\section{Labyrinthula minuta sp.nov.}

Status vegetalis in agare a sero sanguine aquaque marina parato est unicellularis, calore camerali. Forma ovalis est aut discoidalis, 5-10 $\mu$. longitudine, $3-5 \mu$. latitudine. Se findit in tetrades per divisiones seriales angulis rectis. Colore vitreus aut pallido-fulvus. Nucleus est sphaeroideus, 1.5-2.0 $\mu$. diametro; est unus nucleolus centralis. $\mathbf{E}$ cellis progreditur rete filamentorum inter se connexorum $\mathbf{0} \cdot 5-1 \cdot 0 \mu$. latitudine; quibus utentes cellae exhibent mobilitatem labilem, saepe regredientem. E cellis vegetalibus filamentisque constat plasmodium retale seu colonia; ad eius limbum nascuntur cellae multinucleatae post septimanam, 8-22 $\mu$. diamentro, singulae habentes 4-64 nucleos. Se frangunt tandem in cellas uninucleatas vegetales; coloniae saepe rubo-fulvae post tres septimanas aut plus. Sori generatio non visa est.

Hab. Seclusa ab Ulva sp. aliisque algis ex oceano Atlantico carptis, Woods Hole, Massachusetts, U.S.A., 1952.

Vegetative stage on serum + sea water agar at room temperature unicellular, oval to discoidal, 5-10 $\mu$. by 3-5 $\mu$., dividing into tetrads by successive division at right angles, colourless to pale orange; nucleus spherical, $1 \cdot 5-2 \cdot 0 \mu$. in diam. with one central nucleolus; cell producing a net-work of interconnected filaments $0 \cdot 5-1 \mu$. wide on which these cells exhibit gliding motility, often reversible, the vegetative cells and filaments constituting the netplasmodium or colony; multinucleate bodies appear at the periphery of the colony after 1 week, 8-22 $\mu$. diameter, 4-64 nuclei per cell, eventually fragmenting into uninucleate vegetative cells; colonies often reddish orange after 3 weeks or more; vegetative stage in broth culture as on solid agar medium except that cells form micro- or macroscopic tufts which may adhere on the glass surface or be suspended in the liquid medium, such tufts appearing orange or colourless. Sori are not generally observed.

Isolated from Ulva sp. and other marine plants collected from the Atlantic Ocean, Woods Hole, Massachusetts, 1952.

\section{ISOLATION AND CULTIVATION}

The initial isolation of Labyrinthula minuta was made from a fragment of green alga, Ulva sp., collected from the undersurface of a landing float at the Woods Hole Oceanographic Institution during the winter of 1952. The follow- 
ing 'hosts' in the Woods Hole region consistently provided us with additional sources of $\boldsymbol{L}$. minuta; the green algae, Chaetomorpha linium, Ulva lactuca, Bryopsis, plumosa, Ectocarpus sp.; the red algae Gracilaria confervoides and Ceramium rubrum; and the flowering plant Zostera marina. We failed to obtain it from Zostera marina from six other areas on the Atlantic seaboard, namely: Prince Edward Island, Canada; New Haven and Milford, Connecticut; Gloucester, Massachusetts; Long Island, New York; Port Erin, Isle of Man. Shores of the Pacific Ocean in North-western United States have not yielded a single specimen of $L$. minuta. However, other species of Labyrinthula have been recovered repeatedly from the same area during the past five years.

The technique of Watson \& Ordal (1957) was employed for the isolation and cultivation, first in mixed culture and later as a pure culture, of the organism currently described. Any of the following media maintained adequate growth of Labyrinthula minuta: (1) 5-10\% (v/v) serum in sea water solidified by $0.9 \%$ agar, or kept liquid in $0.1 \%$ agar; (2) a liquid, partially defined medium described by Vishniac \& Watson (1953); (3) a liquid defined medium formulated by Vishniac (1955).

Laybrinthula minuta grows most rapidly at $20-25^{\circ}$ but it can be cultivated at a maximum temperature of $35^{\circ}$ and a minimum of $10^{\circ}$. For stock cultures, $15^{\circ}$ has proved most reliable. All microscopic observations have been made at room temperatures $\left(21-28^{\circ}\right)$.

\section{COLONIAL MORPHOLOGY}

The vegetative colony of Labyrinthula minuta is composed of individual cells interconnected by their hyaline mucoid filaments (Pl. 1, fig. 7), forming a netplasmodium. However, this network is demonstrable only with magnifications of $\times 400$ or higher, and when viewed with lower magnifications the cells appear to be scattered at random on the agar surface (Pl. 1, fig. 1). In contrast, the net-plasmodium in other species of Labyrinthula can be observed easily with much lower magnifications (Pl. 1, fig. 2). Two characteristics account for this striking difference, namely: the loose arrangement of the cells on the tracks in L. minuta and the extreme delicacy of the mucoid filaments formed by this species. (1) The cells usually exist in small clusters of four to eight, or as single cells, separated by distances of 10-100 $\mu$. on the connecting filaments. Rarely are the cells lined up on the tracks so that each cell is immediately adjacent to and touching the cell in front and behind it. In all forms of Labyrinthula the very thin tracks are too hyaline to be observed under very low magnifications. However, in the larger and earlier described forms the colony appears as a network even under low magnifications because the cells are closely queued and aligned abreast of each other on the tracks (Pl. 2, fig. 8). (2) The filaments of $L$. minuta are only 1-2 $\mu$. wide (Pl. 1, fig. 7), and the cells travel only in single file on these thin filaments. Although extremely fine filaments are also found in other forms of Labyrinthula, broad filaments up to $50 \mu$. wide are commonly observed, and upon these pathways (Pl. 2, figs. 8, 9) 2-20 cells are frequently seen advancing abreast of one another. 


\section{CELLULAR MORPHOLOGY AND MOTILITY}

\section{Cell size}

The development of relatively simple methods for isolating and propagating Labyrinthula in pure culture (Watson \& Ordal, 1957) has enabled us to compare $L$. minuta with many strains representing other marine species of this genus. An isolate of Labyrinthula believed to represent $L$. vitellina Cienk. is used here for photographic comparison because it is the best defined of all existing species. Except for cell size, the six species previously described would appear to be

Table 1. Reported dimensions of vegetative cells in species of Labyrinthula

\section{Species}

(1) L. minuta sp.nov.

(2) L. macrocystis Cienkowski

(3) L. macrocystis Cienkowski

(4) L. macrocystis Cienkowski

(5) L. vitellina Cienkowski

(6) L. zopfii Dangeard

(7) L. zopfii Valkanov*

(8) L. cienkoreksii Zopf

(9) L. chattonii Dangeard

(10) Labyrinthomyxa sauvageaui Duboseq

(11) Pseudoplasmodium aurantiacum Molisch

\begin{tabular}{l}
\multicolumn{1}{c}{ Observer } \\
\multicolumn{1}{c}{-} \\
Cienkowski (1867) \\
Renn (1936) \\
Young (1943) \\
Cienkowski (1867) \\
Dangeard (1910) \\
Valkanov (1929) \\
Zopf (1892) \\
Dangeard (1932) \\
Duboscq (1921) \\
Molisch (1926)
\end{tabular}

Length Width

$(\mu) \quad.(\mu$.

5-10 3-5

18-25 4-5

10-20 5-8

8.5-30 4

12-17 3-4

Not given

8

11-20

Not given

6-8

7-9

* Karling changed this species name to L. valkanovii (Amer. J. Bot. 1944, 31, 50).

indistinguishable in the vegetative stage. These species, together with the relative sizes of the vegetative cells, as reported by the describers and subsequent investigators, are presented in Table 1 . The only species whose cell dimensions approximate to those of $L$. minuta are Labyrinthomyxa sauvageaui Duboscq, Pseudoplasmodium aurantiacum Molisch, and Labyrinthula zopfii Valk. Upon the basis of size alone, a clear-cut separation of $L$. minuta from these three species is impossible; however, it would appear to be easily distinguishable from them, as well as from all other species, by the shape of its vegetative cells and by the larger, multinucleate forms which it produces in older cultures.

\section{Cell shape}

All species listed in Table 1 have fusiform vegetative cells (Pl. 1, fig. 3) except Labyrinthula minuta which has predominantly oval cells (Pl. 1, figs. 4, 7). Occasionally, they may appear elongated with tapered ends, this aspect appearing when an individual cell attempts to conform to the shape of the slime track. The cells of $L$. minuta exhibit less flexibility than do those of the larger species which frequently bend or constrict when passing a barrier (Pl. 1, fig. 6) or may alternatively become extremely elongated and distorted as they conform to the contour of the track. 


\section{Cell motility}

Labyrinthula minuta, like other members of this genus, has a gliding type of motility restricted to its preformed slime tracks. It differs from other species of Labyrinthula in its much slower rate of movement and in the ability to reverse its direction of movement. The movement of $L$. minuta is extremely slow, 4-5 $\mu$. $/ \mathrm{min}$., and it is perceptible only with a $4 \mathrm{~mm}$. or oil-immersion objective. The rate of movement of only two other species has been reported in the literature; Cienkowski stated that $L$. vitellina moved $12 \cdot 5-25 \mu . / \mathrm{min}$. while Young observed $L$. macrocystis to travel at $150 \mu . / \mathrm{min}$. Considerable variation in rates of movement have been observed in these larger species when cultivated in this laboratory, and oftentimes cells in one area of a given culture would be moving as slowly as $15-30 \mu$. $/$ min., whereas those in other areas were moving at the rate indicated by Young. The slow rate of cell movement in $L$. minuta provides a distinctive and valuable differential characteristic for the diagnosis of this species.

Labyrinthula minuta is apparently unique in the capacity of its cells to reverse their direction of movement on a slime track. Of the reports cited in Table 1, only that of Cienkowski provided information on this point, and he was specific in stating that the cells of $L$. vitellina and $L$. macrocystis did not reverse their direction of movement. Such cells never continue movement for more than $20 \mu$. in a given direction. After moving for this or a lesser distance the cells either stop for an indefinite period or immediately reverse their direction. Such a lack of continuous movement is rarely seen in the larger species where cells and groups of cells commonly move one or more millimetres without stopping. Since the movement of $L$. minuta is so slow and is reversed after such short distances, one never observes the mass streaming motility which is so typical of the larger species, and which has come to be accepted as such a distinctive characteristic of the genus Labyrinthula (Pl. 2, fig. 8). As one would anticipate, cell divisions may be witnessed most commonly when cells of $L$. minuta remain motionless on the slime track.

\section{Cell division and generation time}

The mode of division of Labyrinthula minuta deviates markedly from the common transverse fission described for and observed in other species of this genus. Two rapid divisions at right angles to one another, followed by a period of longer duration when the cells increase in size, characterize and distinguish the vegetative multiplication of this species. The first division is transverse and occurs when the cell has reached its maximum dimensions (i.e. $5 \mu$. wide $\times 10 \mu$. long). The two cells remain attached and often the line of division becomes obscured. The daughter cells usually divide within $\mathbf{3 0} \mathrm{min}$. the plane of this second division occurring at right angles to that of the first (Fig. 1).

Following the second division, the cells may move apart immediately, but more commonly they remain in a tetrad formation for several hours prior to separation (Pl. 1, fig. 5). After the second division, each cell increases in size 
during the next $6-8 \mathrm{hr}$, by when it has once again reached its maximal size for two successive divisions. Thus, under optimal conditions, four daughter cells may be produced from each single cell on an average of about once every $8 \mathrm{hr}$. This was determined by observations of growing vegetative cultures, and by isolating single cells and following their increase in number for 32-43 hr. periods. The data for this latter experiment is presented in Table 2.
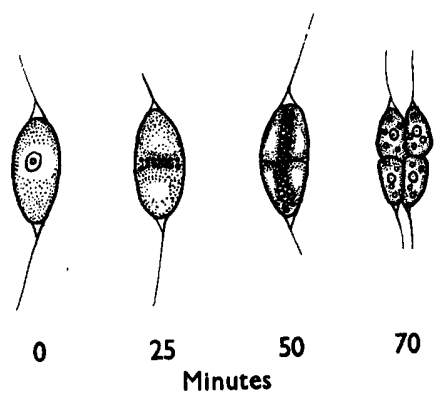

70

Fig. 1. A cell of Labyrinthula minuta dividing into tetrads.

Camera lucida drawing. $\times 1050$.

Table 2. Increase in cell numbers with time from isolated single cells of Labyrinthula minuta

Isolate of L. minuta

$\begin{array}{crccc}\begin{array}{c}\text { Time of } \\ \begin{array}{c}\text { observation } \\ \text { (hr.) }\end{array}\end{array} & \text { No. 1 } & \begin{array}{c}\text { No. 2 } \\ \text { Progeny }\end{array} & \begin{array}{c}\text { No. 3 } \\ \text { (no. of cells) }\end{array} & \text { No. 4 } \\ 0 & \overbrace{1} & 1 & 1 & 1 \\ 5 & 1 & 4 & 4 & 4 \\ 8 & 4 & 4 & 4 & 4 \\ 18 & 16 & 16 & 28 & 42 \\ 19 & 16 & 22 & 60 & 60 \\ 23 & 44 & 29 & 64 & 68 \\ 26 & 54 & 54 & 64 & 98 \\ 32 & 145 & 68 & 126 & 220^{*} \\ 43 & - & - & - & 576^{*} \\ & & * \text { Estimated. } & & \end{array}$

\section{Nucleus}

Because of the peculiar sequence of cell division in Labyrinthula minuta just described, nuclear divisions were followed in relationship to cytokinesis. Such divisions could not be followed in living cultures since the cytoplasm obscured the nuclei during this process; however, it was possible to follow this sequence by studying impression smears prepared by the Feulgen reaction or by staining with iron haematoxylin. Mitotic figures were easily seen in these preparations. Before the first cytoplasmic division, the nucleus divides mitotically with the mitotic figure arranged at right angles to the long axis of the cell, and two interkinetic nuclei are seen just before the first cytoplasmic division. Following the primary division, the nuclei again divide mitotically, the mitotic figures in this case being in a plane at an angle of $90^{\circ}$ to the first 
nuclear division. Since two divisions occur in a single cell within an hour the mitotic divisions obviously occur very rapidly, and it is estimated that only 15-20 min. elapse during each nuclear division. During the second division mitosis is synchronous, or nearly so, in the two sister cells.

The interkinetic nucleus observed with the phase-contrast microscope is spherical, 1.5-2 $\mu$. in diameter and is centrally located in the cell (Pl. 1, figs. 4, 7). The nucleolus is $1 \mu$. in diameter, occupies a central position in the nucleus, stains intensely with iron or Harris's haematoxylin, and is Feulgen negative.

\section{Cytoplasm}

The only cytoplasmic structures visible in living cells of Labyrinthula minuta are 4-15 small granules $0 \cdot 2-0 \cdot 6 \mu$. in diameter (Pl. 1, fig. 7), distributed at random throughout the cytoplasm, and these become aligned along the axis of division just before the completion of cytokinesis (Fig. 1). Because of this interesting feature the nature of these granules was investigated. In Helly's fixed smears, stained with acid aniline fuchsin and methyl green, one to five mitochondria/cell were demonstrable, these being the size of the smallest granules observed in the living cells. However, no alignment of the mitochondria along the axis of division was seen. When preparations were stained with Sudan Black many lipid granules became apparent which showed the same distribution and alignment as granules seen in living cells during and after division. It seems probable, therefore, that the majority of the granules observed in living cells are lipid storage granules. The larger species also have many granules which are visible in the living cell, disappear when treated with fat solvents, and stain with Sudan Black and other fat stains. Unlike the fat granules in L. minuta, those of the larger species do not change position during cytokinesis.

\section{Multinucleate bodies}

Labyrinthula minuta is the only member of the genus known to regularly develop relatively large multinucleate structures when grown on a solid agar medium. Such forms occur only within the first centimetre of growth at the periphery of the colony in cultures aged 1 week or more.

These multinucleate bodies vary in size, shape and number of nuclei. In 7-day culture the largest form found was only $10 \mu$. in diameter (Pl. 2, fig. 13), whereas in 20 to 30-day cultures many bodies were $18-\mathbf{3 0} \mu$. in diameter (Pl. 2, figs. 10-12 and 14). These structures are usually oval to round (Pl. 2, fig. 10), but may be oblong or angular when compressed by other cells. They rarely contain more than 4-8 nuclei ( $\mathrm{Pl} .2$, fig. 13) in a 7-day culture, while in monthold cultures they not uncommonly contain 16 to 64 nuclei/body (Pl. 2, figs. 11, 14).

This multinucleate body apparently develops from a single, normal negative cell, although this could not be substantiated by observations of single cells in living culture alone. From the study of stained slides in conjunction with living cultures, it seems probable that the multinucleate body develops by the enlargement of a vegetative cell which undergoes repeated synchronous nuclear 
divisions in the absence of cytokinesis which is suppressed longer in older cultures than in cultures 1-2 weeks old. In the younger cultures cytoplasmic cleavage is initiated in cells with only 4-8 nuclei, while in older cultures cytokinesis often does not occur until there are $c$. 64 nuclei in one body.

Apparently, the multinucleate bodies cleave eventually into uninucleate vegetative cells (Pl. 2, fig. 12), for only the latter can be observed in the older portions of the expanding colony. However, the complete cleavage of any large body into an appropriate number of uninucleate components has not been observed in the living state. We know that this occurs slowly and is not synchronous. Living multinucleate bodies have been observed continuously for $48 \mathrm{hr}$., and during this period unequal cleavage of the cytoplasm took place, but the large bodies did not fragment completely into uninucleate cells. In one instance, several uninucleate cells did separate off, but a considerable portion of the large body retained its multinucleate structure. In other instances unequal cleavage resulted in two or more smaller multinucleate bodies and one or two cells with single nuclei. Examination of stained smears led us to conclude that these smaller multinucleate cells eventually cleave into uninucleate cells.

\section{DISCUSSION}

If we accept the broad definition of a plasmodium as an unwalled, multinucleate mass of protoplasm, then the term plasmodia can be applied to the multinucleate bodies of Labyrinthula minuta. Plasmodia are also found in the Myxomycetes, the Plasmodiophorales, and the Myxosporidiae. The basic common characteristic of the plasmodia of these four groups of organisms is the condition of multinucleation. The four types of plasmodia may be compared and contrasted as to their formation and their resolution.

Since the plasmodium of Labyrinthula minuta arises, apparently, from a single non-amoeboid, haphoid cell it is unlike the diploid plasmodium of the Myxomycetes and the Plasmodiophorales. These plasmodia arise from the fusion of two swarm cells or myxamoebae. On the other hand, certain of the Plasmodiophorales do possess a second plasmodial stage which arises from a single haploid amoeboid cell. In certain species of the Myxosporidiae haploid amoebulae penetrate host tissue, grow in size, and undergo schizogony cutting off uninucleate schizonts. Each schizont develops into a multinucleate amoeboid plasmodium.

Little or no similarity exists in the ultimate transformation of the mature plasmodium in Labyrinthula minuta, the Myxomycetes, the Plasmodiophorales and the Myxosporidiae. In the Myxomycetes the entire plasmodium is converted into one or more fruiting bodies while in the Plasmodiophorales and the Myxosporidiae the plasmodium eventually cleaves into spores. In contrast, the plasmodium of $\boldsymbol{L}$. minuta fragments into uninucleate or multinucleate vegetative cells. Spores have never been seen in this species. Thus, possession of a multinucleate stage is not adequate evidence for relating $L$. minuta to these three other groups of organisms.

In a paper published in 1953, relating to the steroid requirements of two 
isolates of Labyrinthula, Vishniac \& Watson applied the name L. minuta var. atlantica to the organism here described. At that time these investigators believed they had two isolates of a minute and distinctive species, and hence used the above name to distinguish one of these in the laboratory. Unfortunately, the name was carried over into the publication just cited. However, no descriptive information or illustrations whatsoever were published concerning the colonial characteristics of the organism or the morphology and dimensions of its cellular elements. Furthermore, additional study of the two strains has shown them to be identical. The foregoing technical description is presented to validate the name $\boldsymbol{L}$. minuta sp.nov, and the epithet incorrectly used earlier should be abandoned.

Type culture material, consisting of stained slide preparations and photomicrographs, has been deposited in the Farlow Herbarium, Harvard University, Cambridge, Mass., and in the Mycological Herbarium, New York Botanical Garden, Bronx Park, New York, New York.

This investigation was supported in part by a research grant, $\mathrm{C}-2119 \mathrm{M}$ and $\mathrm{G}$, from the National Cancer Institute, of the National Institutes of Health, Public Health Service.

\section{REFERENCES}

Archer, W. (1875). On Chlamydomyxa labyrinthuloides. Quart. J. micro. Sci. 15, N.S., 107.

Cienkowski, L. (1867). Über den Bau und die Entwickelung der Labyrinthuleen. Arch. mikr. Anat. 3, 274.

Dangeard, P. A. (1910). Études sur le développement et la structure des organismes inferieurs. Botaniste, 1, 58.

Dangeard, P. A. (1932). Observations sur la famille des Labyrinthulées et sur quelques autres parasites des Cladophora. Botaniste, 24, 217.

DuboscQ, O. (1921). Labyrinthomyxa sauvageaui protéomyxée parasite de Laminaria lejolisii Sauvageau. C.R. Soc. Biol., Paris, 84, 27.

MoLisch, H. (1926). Pseudoplasmodium aurantiacum n.g. et n.sp. eine neue Acrasiee aus Japan. Sci. Rep. Tôhoku Univ., 4th series, no. $1,119$.

Renn, C. E. (1936). The wasting disease of Zostera marina. Biol. Bull., Woods Hole, 70, 148.

Valkanov, A. (1929). Die Natur und die systematische Stellung der Labyrinthuleen. Arch. Protistenk, 67, 110.

Vischniac, H. S. (1955). The nutritional requirements of isolates of Labyrinthula spp J. gen. Microbiol. 12, 455 .

Vischniac, H. S. \& Watson, S. W. (1953). The steroid requirements of Labyrinthula vitellina var. pacifica. J. gen. Microbiol. 8, 248.

Watson, S. W. \& Ordal, E. J. (1957). Techniques for the isolation of Labyrinthula and Thraustochytrium in pure culture. J. Bact. 73, 589.

Young, E. L. (1943). Studies on Labyrinthula the etiologic agent of the wasting disease of eel-grass. Amer. J. Bot. 30, 586.

Zopf, W. (1892). Zur Kenntniss der Labyrinthuleen, einer Familie der Mycetozoen. Beit. Physiol. Morph. nied. Organ. 2, 36. 
Journal of General Microbiology, Vol. 17, No. 2
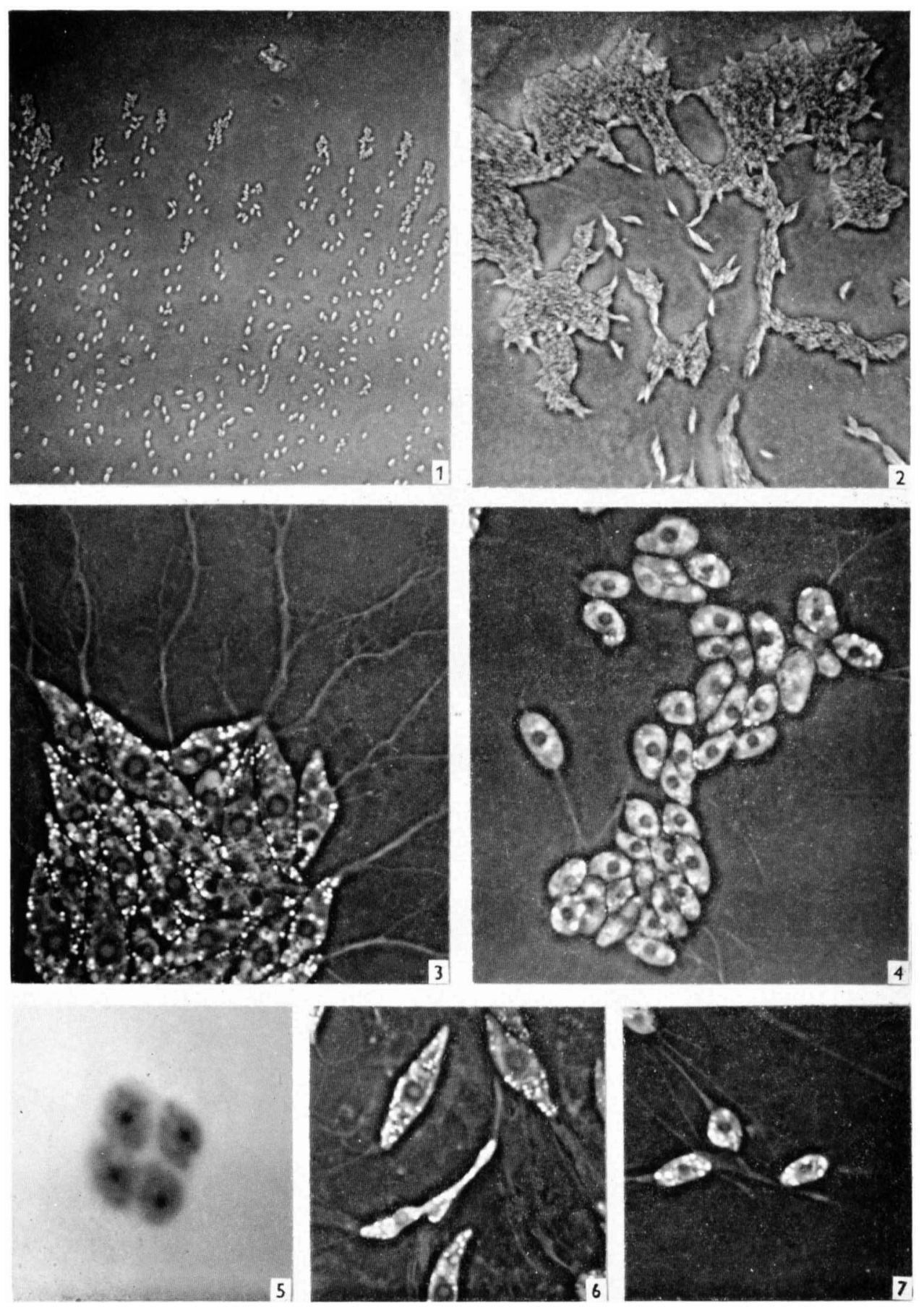

S. W. Watson and K. B. Raper-Labyrinthula minuta sp.nov. Plate 1

(Facing $p$. 376) 
Journal of General Microbiology, Vol. 17, No. 2
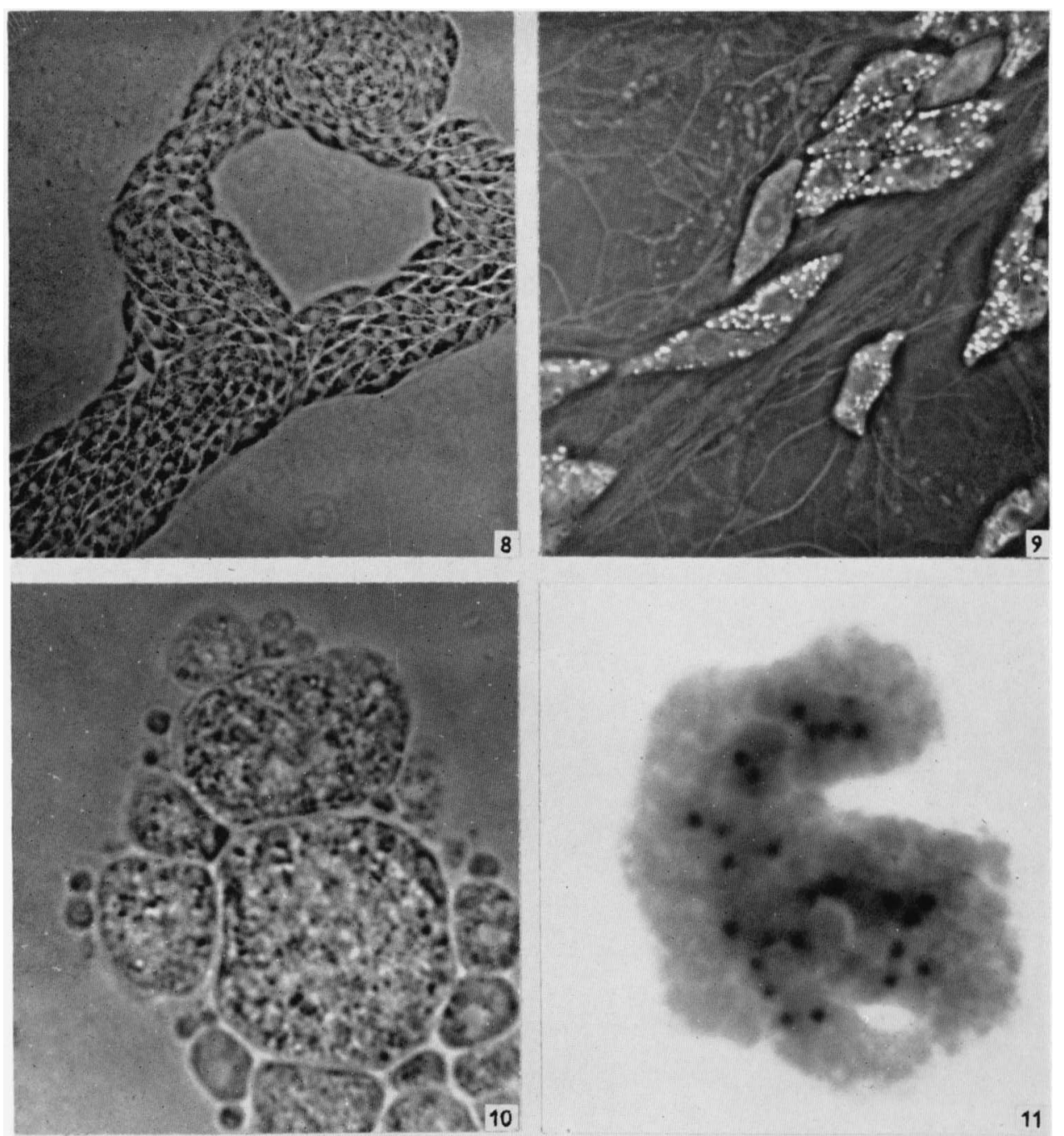

11
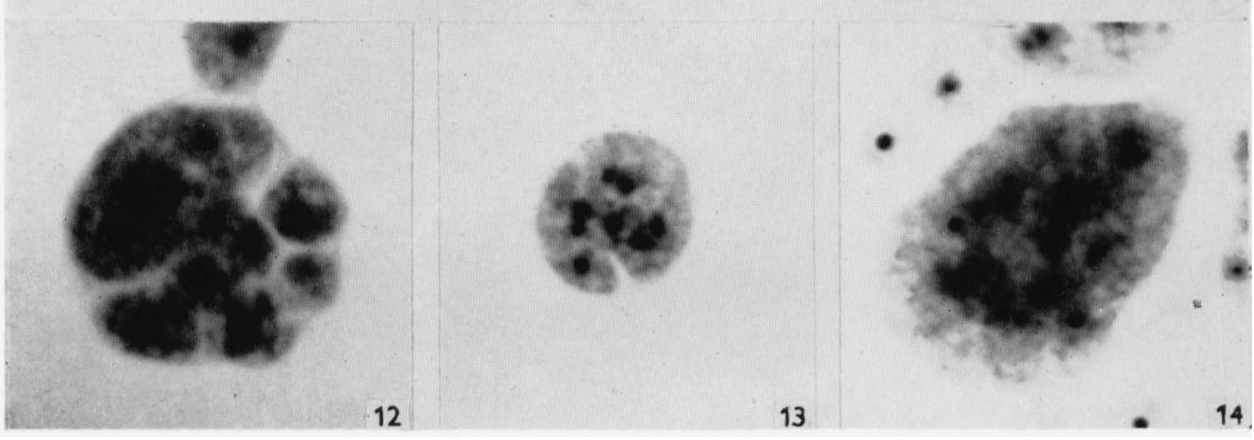

S. W. Watson and K. B. Raper-Labyrinthula hinuta sp.nov. Plate 2 


\section{EXPLANATION OF PLATES}

\section{Plate 1}

Fig. 1. Labyrinthula minuta growing on an agar surface. Phase-contrast photomicrograph showing distribution of cells in a colony. $\times 150$.

Fig. 2. L. vitellina growing on an agar surface showing the net-plasmodium. $\times 150$.

Fig. 3. L. vitellina growing on an agar surface. A phase-contrast photomicrograph showing fusiform cells at the edge of a colony. $\times 900$.

Fig. 4. L. minuta growing on an agar surface. A phase-contrast photomicrograph showing oval cells with centrally located nuclei. $\times 900$.

Fig. 5. L. minuta stained with iron-haematoxylin showing arrangement of cells in a tetrad. $\times 1425$.

Fig. 6. L. vitellina growing on an agar surface. Phase-contrast photomicrograph showing distortion of a cell during migration. $\times 900$.

Fig. 7. L. minuta growing on an agar surface. Phase-contrast photomicrograph showing shape of cells, internal structures, and the slime filaments connecting the cells. $\times 900$.

\section{Plate 2}

Fig. 8. L. vitellina growing on an agar surface. Phase-contrast photomicrograph showing many cells moving abreast on portion of the net-plasmodium. $\times 250$.

Fig. 9. L. vitellina growing on an agar surface. Phase-contrast photomicrograph showing broad tracks of the net-plasmodium. $\times 900$.

Fig. 10. L. minuta growing on an agar surface showing large multinucleate bodies of varied dimensions. $\times 1425$.

Fig. 11. L. minuta stained with iron haematoxylin showing multinucleate large body from a 30-day culture. $\times 1900$.

Fig. 12. L. minuta stained with iron haematoxylin showing fragmentation of multinucleate body into uninucleate cells. $\times \mathbf{1 4 2 5}$.

Fig. 13. L. minuta stained with iron haematoxylin showing the initiation of cleavage of a small multinucleate body from a 7 -day culture. $\times 1425$.

Fig. 14. L. minuta stained with iron haematoxylin showing multinucleate body from a 30-day culture. $\times 1425$. 